Oliwia GromadzKa

Uniwersytet im. Adama Mickiewicza w Poznaniu

\title{
Krajobraz japoński w polskich narracjach podróżniczych przełomu lat 8o. i 90. XIX wieku
}

Relacja Europejczyka z przestrzeniami i kulturami nieeuropejskimi w wymiarze kolonialnym stanowi przedmiot obfitującej w literaturę dyskusji. Wiodącymi w niej kwestiami są m.in.: rola Europejczyka w narracji o „obcych” mu obszarach, kategoryzacja przedstawicieli społeczeństw pozaeuropejskich oraz stosunek Europejczyka do kolonizowanej przestrzeni, poruszane chociażby przez Edwarda Saida, Mary Louise Pratt czy Denisa Cosgrove’a. Niniejszy artykuł ma za cel zawężenie przedmiotu tej refleksji do polskiego kontekstu podróżniczego i wyłuskanie z niego portretu krajobrazu dalekiego kraju na tle motywów charakterystycznych dla zachodnioeuropejskiego myślenia imperialnego.

Za przykład obrałam japoński krajobraz końca XIX wieku, przybliżony odbiorcom w latach dziewięćdziesiątych tegoż stulecia pod postacią trzech publikacji podróżniczych wydanych przez polskich autorów. Stanowią one przy tym kompletny zestaw polskich relacji podróżniczych $\mathrm{z}$ tego kraju z drugiej połowy XIX wieku. Japonia, będąca jednym $z$ celów analizowanych przeze mnie wypraw, cieszyła się w tym okresie szczególnym zainteresowaniem polskich środowisk artystycznych i intelektualnych ze względu na zyskujący na popularności japonizm ${ }^{1}$, będący źródeł wiedzy i fascynacji tym krajem również dla omawianych autorów.

1 Japonizm był czerpiącym z motywów kultury japońskiej trendem w sztuce europejskiej, zapoczątkowanym na przełomie lat sześćdziesiątych i siedemdziesiątych XIX wieku 
Trzy dzieła, na których opieram się w niniejszym artykule, stanowią wyjątkowy przykład narracji o miejscach, które do tej pory pozostawały nieopisane przez polskich podróżników (Kluczewska-Wójcik 2016: 132). Są to Na około Ziemi. 1888-1889 Karola hrabiego Lanckorońskiego, Podróże na Wschód Azji. 1888-1889 Pawła Sapiehy oraz Jedna z podróży na około Ziemi. Tom 2 autorstwa Hugona Zapałowicza. Autorzy ci stanowili reprezentację polskich elit intelektualnych na terenie Cesarstwa Austro-Węgierskiego - Karol Lanckoroński jako polityk i kolekcjoner sztuki, Paweł Sapieha jako zaangażowany politycznie działacz społeczny oraz Hugo Zapałowicz jako żołnierz armii cesarskiej i botanik. Niezależnie od siebie odwiedzili oni Japonię na przełomie lat osiemdziesiątych i dziewięćdziesiątych XIX wieku, dostarczając swoim czytelnikom obrazu społeczeństwa, kultury i przestrzeni, która do tej pory znana im była jedynie z dzieł sztuki i literatury obcej. Choć każdy z nich skupił swoją uwagę na innych elementach odwiedzanych miejsc, pojawiające się opisy krajobrazu pozwalają czytelnikowi nakreślić mapę powielających się wyobrażeń o obserwowanej przez nich przestrzeni.

Percepcja japońskiego krajobrazu ograniczona była do ścisłych przestrzeni geograficznych odwiedzanych przez autorów. Porównanie tekstów wskazuje na wyznaczone szlaki, jakimi się poruszali, obejmujące największe ośrodki miejskie - Osakę, Kioto i Tokio, miejsca ważne pod względem komunikacyjnym - port w Jokohamie, Kobe i Nagasaki, oraz miejsca istotne z punktu widzenia tradycji politycznej i kulturowej - pałac Mikado w Tokio i Osace, świątynie w okolicy Kamakury, zamki szogunów. Do szczególnych przestrzeni krajobrazowych zaliczyć można miejsca o wymiarze symbolicznym, takie jak góra Fudżi. Powtarzalność tras sugeruje, że okolice te stanowiły dla europejskich podróżników stały element wycieczek po Japonii. Zaznaczyć jednak należy, że choć część nazw najważniejszych z odwiedzanych przez autorów lokalizacji pojawia się w tekście, to niejednokrotnie identyfikacja poszczególnych obszarów może być utrudniona, zwłaszcza jeżeli podróż obejmuje pomniejsze obiekty sakralne, mniej znane dzielnice miejskie lub okolice wiejskie.

Osobiste zainteresowania, doświadczenia podróżnicze oraz konteksty imagologiczne, jakie charakteryzowały każdego z autorów, zapewniały zróżnicowany

we Francji. Największe odbicie znajdował w malarstwie, sztuce użytkowej oraz kolekcjonerstwie. Na ziemiach polskich apogeum zainteresowania japonizmem przypadło na ostatnią dekadę wieku XIX i pierwszą dekadę wieku XX, a za jednego z najwybitniejszych japonistów polskich uważa się kolekcjonera Feliksa Jasieńskiego. O recepcji sztuki japońskiej w sztuce polskiej zob. np. Albertowa, Kossowski 1981; Król 2011; Kluczewska-Wójcik 2016; Kossowski, Martini 2016. 
nacisk na wybrane szczegóły w odbiorze przestrzeni oraz sposób prowadzenia narracji. Przekładało się to również na liczbę i charakter opisów zastanych w Japonii krajobrazów. Najmniej opisów krajobrazu dostarcza Sapieha, który wprost zaznacza, że: „pisząc romans, opisywałbym naturę; pisząc dziennik podróży, notuję tylko ogólnikowo wrażenia” (Sapieha 1899: 188), czyniąc tym samym swoje dzieło najbardziej ubogim w takie portrety. Znacznie więcej informacji dostarcza Lanckoroński, a szczególnie cenne dla interpretacji jego tekstu są elementy porównawcze oraz wiedza autora na temat japońskiej sztuki. Z kolei Zapałowicz wyróżnia się na tle pozostałych autorów ze względu na umiłowanie do botaniki, która markuje jego narrację opisami o znamionach naukowości, mieszającymi się jednak z licznymi uromantycznionymi notatkami, dostarczającymi kwiecistych opisów pejzaży oraz zjawisk przyrody. Mimo indywidualnego charakteru każdej z omawianych narracji podróżniczych czytelnikowi z łatwością przychodzi wychwycenie powtarzających się w nich cech, które - zebrane i porównane ze sobą - tworzą pokrewne portrety japońskiej przestrzeni.

Opisy te otwierają szerokie pole interpretacyjne, które na potrzeby tego artykułu zamknąć należy w określonym korpusie kategorii, dostarczanych zarówno przez teorię postkolonialną, jak i geopoetykę. Definicja tej drugiej przedstawiona została przez Elżbietę Rybicką jako „orientacja, której celem jest badanie interakcji pomiędzy twórczością literacką a przestrzenią geograficzną” (Rybicka 2014: 10). Zacząć należy jednak przede wszystkim od pojęcia krajobrazu, które w kontekście percepcji japońskiej przestrzeni w polskich tekstach podróżniczych nabiera złożonego charakteru. Problem pojawia się już na poziomie definicji, których wielość utrudnia syntetyczne ujęcie sposobu rozróżnienia poszczególnych rodzajów krajobrazu. Podstawowe bowiem rozróżnienie krajobrazu na „naturalny”, utożsamiany z przyrodą, oraz „kulturowy”, związany z działalnością człowieka, w próbie uściślenia ujawnia swoją niejednoznaczność. Dorota Angutek teorię krajobrazu rozpatruje głównie w perspektywie antropologicznej, wychodząc od trzech definicji: krajobrazu naturalnego, definiowanego jako „teren użytkowo zagospodarowany z enklawami swobodnie rosnącej dzikiej roślinności”, rozumianego jako pastwiska czy lasy, kulturowego zaprojektowanego całkowicie „dla potrzeb estetycznych i celów rekreacyjnych”, jak parki, oraz pierwotnego, będącego wolnym od „ludzkiej ingerencji” (Angutek 2013: 31-32). Propozycja ta pokrywa się z definicją przedstawioną przez Stanisława Pietraszkę, który dzieli krajobraz na dwie kategorie: „naturalnie wyodrębniony” związany z przyrodą oraz, definiowany przez niego z kolei za Tadeuszem Szczęsnym i Marią Dobrowolską (Dobrowolska 1948: 156; Szczęsny 1982: 107-108), „kulturowy”, to jest taki, który charakteryzuje się ingerencją człowieka. Z kolei Beata Frydryczak wyznacza różnicę „między krajobrazem 
jako ideą (krajobrazem estetycznym) odwołującą się do bezczasowości pięknej natury a krajobrazem jako procesem (krajobrazem kulturowym) przebiegającym w granicach tego co społeczne i kulturowe" (Frydryczak 2013: 163).

Definicje te łączą się z wyartykułowaną w narracji podróżniczej rolą interpretacji, którą narzuca obserwator percypujący krajobraz. Jego postawa wobec obszarów naturalnych nie tylko określa stosunek do krajobrazu wyrażany w opisie, ale również nadaje krajobrazowi moc znaczeń, definiując ostatecznie formę jego istnienia (Frydryczak 2013: 163). Oznacza to, że choć formułowane współcześnie definicje krajobrazu stanowić mogą pewną ramę interpretacyjną dla badaczy, to jednak konteksty ujawniające się w tekstach podróżniczych wymykać się mogą próbom doprecyzowania pojęć.

Rola obserwatora ma również znaczenie z punktu widzenia „spojrzenia kolonialnego". Pisze o nim Said, który nazywa narratora opowieści o Oriencie "obserwatorem oddzielonym”, czyli takim, który opisuje Orient, „odkrywając jego tajemnice", wyjaśniając go (Said 2005: 55), a jednocześnie, jako przedstawiciel innej kultury, podkreślając swoją odrębność wobec tego, co ogląda. Podobnie narratora opowieści orientalnej opisuje Mary Louise Pratt, która w swojej książce omawia kwestię imperialnej retoryki funkcjonującej w nowożytnym podróżopisarstwie. Autorka nazywa obserwatora „człowiekiem oglądającym”, czyli Europejczykiem, który „patrzy i zawłaszcza” krajobraz, przyjmując rolę „władcy” oglądanych przestrzeni. Ma on moc opisywania oraz poddawania ocenie tego, co widzi (Pratt 2011: 27).

Wzrok kolonialnego obserwatora spoczywał na przestrzeni, skupiając się na jej poszczególnych elementach - tubylcach wraz z ich cechami fizycznymi, ubiorem oraz zachowaniem czy krajobrazie i składających się na niego górach, nabrzeżach naturalnych i portowych, wodospadach, jeziorach, wpisujących się w niego wioskach i miasteczkach. Narrator następnie opisywał przestrzeń, posługując się zabiegami stylistycznymi i kategoriami opisu, które wyznaczały granicę między nim samym, jako przedstawicielem kultury i estetyki europejskiej, a nieeuropejskim otoczeniem. Tubylcy w tej narracji przedstawiani byli w roli ludów „dzikich”, nieucywilizowanych. Kreślono w ten sposób różnicę, nazwaną przez Anię Loombę „binarną opozycyjnością” (Loomba 2011: 74), i „udzielano” sobie prawa do zawłaszczenia i rozporządzania ziemią należącą do ludów nieeuropejskich, ignorując ich potencjał kulturowy (Cosgrove 2014: 108) i zaliczając ich do „środowiska przyrodniczego”.

Pierwszą z tych kategorii są wyobrażenia i symbole „orientalnych” przestrzeni, których źródło stanowi konglomerat wiedzy (stereotypów) o Oriencie, jakimi dysponowali Europejczycy (Said 2005: 38). W ich skład wchodziły między innymi „symbole” przestrzeni orientalnych, takie jak charakterystyczne 
szczyty górskie, nabrzeża, wodospady czy jeziora. Elementy te składały się na złożone imagologie terytorialne (Rybicka 2014: 203-205) dotyczące całego obszaru Cesarstwa Japonii oraz zamieszkujących go Japończyków. Orientalne klisze składały się również na wspomniane już przekonanie o braku „potencjału kulturowego” ludów nieeuropejskich, które prowadziło do postrzegania ich jako części lokalnego środowiska przyrodniczego. Zarówno „dzikie” społeczności, jak i wytwory ich pracy, w tym dzieła architektoniczne, stawały się na tej podstawie integralną częścią natury. Sama natura w omawianych przeze mnie tekstach sprowadzana była przede wszystkim do wartości estetycznych, a ocena, jakiej ją poddawano, zależna była od tego, na ile jej widok był „przyjemny” dla oka obserwatora (Pratt 2011: 287). Ważny element narracji stanowiły również porównania, których dokonywano, zestawiając obserwowany krajobraz japoński ze znanymi sobie przestrzeniami z Europy i Bliskiego Wschodu. I choć w większości z nich to krajobrazy europejskie stanowiły źródło odwołań porównawczych, to dostrzegalny jest również pojedynczy zabieg odwrócenia przyjętej konwencji. W przypadku narracji Lanckorońskiego jest to odwrócenie idei kierunku przepływu kulturowego, który tradycyjnie zakładał, że to cywilizacja europejska jest dostarczycielką myśli oświeceniowych oraz rozwoju społecznego i ekonomicznego (Pratt 2011: 196).

\section{Wyobrażenia i symbole w narracjach o krajobrazie japońskim}

Pośród wspomnianych kategorii kształtujących europejski obraz krajobrazu japońskiego ważnym elementem były jego przedstawienia i wynikające z nich wyobrażenia. Końcówka wieku XIX w odniesieniu do Dalekiego Wschodu charakteryzowała się w Europie silnym zainteresowaniem sztuką japońską, które pod postacią malarstwa, kolekcjonerstwa czy literatury upowszechniało elementy kultury japońskiej (Kluczewska-Wójcik 2016: 23-40). Wpływy te widoczne są również w tekstach, np. w tych fragmentach, w których Lanckoroński odwoływał się do swojej wiedzy na temat drzeworytnictwa japońskiego (zob. np.: Lanckoroński 1893: 219-223, 228-229), a Sapieha krytykował nieadekwatność zachodnich opowieści literackich o Japonii (zob. np. Sapieha 1899: 165). Te źródła wiedzy produkowały wielopłaszczyznowe wyobrażenia na temat Japonii, które pod koniec XIX wieku były przede wszystkim nacechowane pozytywnie. W ten sposób, w odniesieniu do kwestii krajobrazowych, formułowały się elementy związanej z Japonią imagologii terytorialnej (Rybicka 2014: 204), zawierającej w sobie określone symbole kojarzone ściśle z tym obszarem geograficznym. Samo pojęcie „imagologii terytorialnej” składa się na szereg cech, które Rybicka przytacza zarówno za geografią wyobrażoną w definicji 
Saida, jak i definicją prezentowaną przez Dictionary of Human Geography, za którym autorka pisze, że jest to:

Przede wszystkim domena kultury i obejmuje ona zarówno reprezentacje miejsc, ludzi, krajobrazów i natury, jak i sposoby, dzięki którym te kulturowe reprezentacje artykułują pragnienia, fantazje, przedsądy ich autorów, a także sieć relacji władzy i dominacji pomiędzy tymi obrazami a przedmiotami reprezentacji (Rybicka 2014: 203-204).

Siłę jej oddziaływania najwyraźniej wyartykułował Sapieha, który zbliżając się do pierwszego japońskiego portu Hiogo, zanotował: „Ale Japonia! Ale Japonia! - jutro staniemy na tej japońskiej ziemi, o której tyle marzyłem, tyle razy śniłem, jak o raju jakimś niedoścignionym! Doprawdy, płakać mi się chce z rozczulenia. Ale czy rzeczywistość odpowie moim oczekiwaniom?..." (Sapieha 1899: 164). Westchnienia do projekcji odległego, nieoglądanego przedtem kraju przesycone są silnymi elementami marzeń i fantazji i kształtują, jak za Jeanem Starobinskim podaje Rybicka, bardzo „pozytywnie zorientowany” stosunek do oczekiwanych doświadczeń (Rybicka 2014: 203).

Wyobrażony zachwyt Sapiehy nie przybrał na tym etapie podróży wyraźnych kształtów, pozostawał zawieszony w postaci ogólnie wyrażonych oczekiwań. Geografia wyobrażona podróżników znajdowała jednak obiekty obierane za symbole terytoriów, do których się odnosiła, utrwalając ich obraz. Spośród omawianych tutaj autorów wyrazicielem takich skonkretyzowanych oczekiwań jest Lanckoroński, który z pokładu statku, zbliżając się do wybrzeży Japonii, zanotował: „Nad najwyższym szczytem górskim na wyspie białe chmury, jak nad Wezuwiuszem [...]. 23 [maja] ujrzeliśmy wybrzeże Japonii, ale niestety nie górę Fusijama, wulkan śnieżysty, Etnę dalekiego wschodu, którego widoku byłem tak chciwy, gdyż szary pokład chmur rozłożył się nad lądem” (Lanckoroński 1893: 202).

Opisy poświęcone górze Fudżi stanowią ważny element relacji odwołujących się do symboli Japonii. Autorzy uznawali ją nie tylko za krajobrazowy symbol tego kraju, ale też stosowali porównania, które ów symbolizm potęgowały - zarówno Zapałowicz, jak i Lanckoroński zestawiali ją ze znanymi sobie z Europy wulkanami włoskimi, dwukrotnie zaś pojawiło się u nich porównanie $\mathrm{z}$ Etną. W zabiegach tych odwoływali się nie tylko do kategorii estetycznych, ale również uwznioślali postać góry, sięgając do romantycznej tradycji nadawania obszarom górskim szczególnych cech piękna i szlachetności (Kowalczykowa 1982: 88-89) oraz zwracając się w stronę skojarzeń ze starożytnościami. Przykładu dostarcza Zapałowicz, który zanotował: 
Słońce już za wulkanem ukryte, rysowało kontur jego nadzwyczajnie subtelnie, bramując jeszcze nikłem światłem szczyt i koronę śniegów. I na myśl mi wciąż przychodził wulkan Etna, którego wyniosłą postać zużytkowali starzy Rzymianie w Catanii jako tło dla sceny teatralnych widowisk (Zapałowicz 1899: 195).

Autor estetyzuje wyłaniający się spomiędzy zabudowań miejskich szczyt, przekształcając jego obraz w opis pejzażowy, uszlachetniony teatralnym tłem włoskiego wulkanu.

Przytoczony fragment z publikacji Zapałowicza stanowi część krótkiego romantycznego opisu wierzchołka góry, wyłaniającego się spomiędzy zabudowań Jokohamy. Autor pisał w nim: „Zamykał daleki widnokrąg olbrzymi stożek z koroną wiecznych śniegów na skroni [...], święta góra Japończyków i główny motyw w ornamentyce i malarskiej sztuce Japonii" (Zapałowicz 1899: 195). Sztuka japońska w kontekście Fudżi pojawia się również u Lanckorońskiego, który także nawiązuje do jej rozpowszechnionego w Europie wizerunku:

Jego szczyt śniegiem pokryty, znany jest z tysiącznych rysunków na wachlarzach, pudełkach, meblach z laku, i możnaby powiedzieć, że sylweta żadnej góry na ziemi nie jest tak rozpowszechniona, jak Fusijamy. Nawet tak często portretowany Wezuwiusz pozostał daleko w tyle [...] (Lanckoroński 1893: 217).

Przedstawienia te stanowią ślad rosnącego wówczas zainteresowania sztuką japońską w Europie. Wspomniany przeze mnie wcześniej japonizm ujawnił się tutaj w pełnej krasie, przyjmując rolę źródła wiedzy o krajobrazie. Za kolejny przykład posłużyć może ponownie Lanckoroński, który w swoim tekście pozostawił jeszcze jeden trop portretów góry Fudżi. Będąc kolekcjonerem i znawcą sztuki (zob. np. Winiewicz-Wolska 2010: 43-78), obcował również z modnymi w drugiej połowie XIX wieku w Europie drzeworytami japońskimi, o których opowiadał przy okazji odwiedzin w muzeach i warsztatach rzemieślniczych w Tokio. Wspominał wówczas o Maruyamie Okyo oraz Hokusaiu, japońskich artystach żyjących odpowiednio w XVIII i na przełomie XVIII i XIX wieku. Wśród ich dzieł znajdowały się również pejzaże z portretem góry Fudżi, a Hokusai poświęcił jej dwa cykle drzeworytów pt. 36 widoków góry Fuji oraz Sto widoków góry Fuji. Jego zainteresowanie dziełami, a następnie możliwość bezpośredniego doświadczenia sztuki w samej Japonii nieco później uczyniła z Lanckorońskiego ważny głos w polskich kręgach artystycznych zainteresowanych japonizmem (Kluczewska-Wójcik 2016: 130-141). 
Mity i obrazy dostarczały określonej „reprezentacji” góry Fudżi, która, wraz z przesiąkniętym japonizmem kontaktem z kulturą Japonii w Europie, w określony sposób kształtowała percepcję tego obiektu naturalnego. Nadawały jej w ten sposób rolę „bohaterki”, która wychodzi poza estetyczne ramy percepcji, i umiejscawiały ją w złożonej całości imagologii terytorialnej odnoszącej się do tego kraju (Por. Rybicka 2014: 204-205). Nawiązanie do świętości w odniesieniu do góry nadaje również trzecie znaczenie temu miejscu. Jego wartość wynoszona jest w oczach dziewiętnastowiecznego turysty do sfery sacrum (Myga-Piątek 2016: 51).

Rola „reprezentacji” krajobrazu japońskiego przypadała także znacznie mniejszym składnikom przyrody. Poszczególne elementy flory mieszają się $\mathrm{w}$ analizowanych przeze mnie narracjach $\mathrm{z}$ dziełem ludzkich rąk, wkraczając na pole dyskusji o granicach krajobrazu kulturowego w postrzeganiu przestrzeni japońskiej.

\section{2. "Japoński duch" w harmonii z naturą - Japończycy jako część krajobrazu naturalnego}

Jak wspomniałam na początku, powszechnie przyjmuje się rozróżnienie pomiędzy naturalnym, wydzielonym od ludzkiej działalności krajobrazem przyrodniczym a całkowicie ukształtowanym przez człowieka krajobrazem kulturowym. Urszula Myga-Piątek wprowadza w swoim tekście o turystycznym sposobie postrzegania krajobrazu dodatkową definicję krajobrazu przyrodniczo-kulturowego, który ukształtowany jest w „wyniku wspólnego działania procesów naturalnych i świadomych modyfikacji form pokrycia terenu i struktury przestrzennej przez człowieka" (Myga-Piątek 2016: 50). Funkcjonujący w drugiej połowie XIX wieku dyskurs kolonialny wymyka się jednak tej współczesnej definicji, roszcząc sobie prawo do wyłączności na „kulturowe” kształtowanie przestrzeni naturalnej. W przypadku badań nad europejską percepcją krajobrazu obszarów nieeuropejskich należałoby uwzględnić ekskluzywność przywileju „panowania” nad krajobrazem, a co za tym idzie jego „ujarzmiania” i kształtowania. Używając argumentów ekonomicznych i kulturowych, uznano ludy pozaeuropejskie za niezdolne do właściwego wykorzystania przyrody i umniejszono je do roli przedmiotu stanowiącego część krajobrazu naturalnego (Cosgrove 2014: 107-108).

Kontekst japonizmu oraz rozpowszechnione przekonanie o roli białego Europejczyka wobec przyrody uosabiało się w postawie podróżnika, który przybierał rolę „obserwatora”, „człowieka oglądającego” (Pratt 2011: 27). Dominujące spojrzenie przybysza uprzedmiatawiało człowieka nieeuropejskiego, czyniąc 
z Europejczyka „pana” kontrolującego i kształtującego obszar naturalny i wchodzące w jego skład ludy tubylcze (Bender 2014: 261). Sytuacja nieskolonizowanej (choć nieeuropejskiej) Japonii różniła się jednak nieco od podporządkowanych imperiom kolonialnym obszarów.

Narracja o Japonii, choć zawierająca silne elementy dyskursu kolonialnego, napotykała na problem japońskiej niezależności oraz dynamicznych przemian zachodzących tam na wzór zachodni na skutek restauracji Meiji ${ }^{2}$ dokonywanych rękami Japończyków, a nie potencjalnych kolonizatorów. Wzorowane na europejskich modelach gospodarczo-politycznych zmiany zauważone zostały również przez każdego $\mathrm{z}$ autorów, którzy dokonywali osobistej oceny widocznych przemian (zob. np. Sapieha 1899: 177; Lanckoroński 1893: 208-210; Zapałowicz 1899: 193, 325). Przełom lat osiemdziesiątych i dziewięćdziesiątych był okresem wkroczenia przez Japonię na drogę radykalnego uprzemysłowienia, niekorespondującego z ideą „,dzikiego” Azjaty, któremu należy dopiero „przedstawić” ideę rozwoju cywilizacyjnego.

Każda $\mathrm{z}$ trzech omawianych przeze mnie prac stanowi ciekawy przypadek mieszanych opinii: od zachwytu nad estetyką i kulturą po sceptycyzm wobec obserwowanych prób przeszczepienia „europejskich” instytucji akademickich (Goody 2009: 234-239) i rządowych na grunt japoński. Działania te zostały jednak w narracjach polskich podróżników zaszeregowane jako próby dorównania (u Sapiehy wymownie nazwanej również „małpowaniem”; zob. Sapieha 1899: 218) państwom europejskim i niejednokrotnie poddane surowej ocenie. Obok pozytywnych stereotypów o pracowitości, inteligencji i wysokim poziomie higieny stosowano również klisze znane z narracji kolonialnej. Ich wykorzystanie miało charakter infantylizujący Japończyków i nadawało im cechy prostych (Lanckoroński 1893: 227; Sapieha 1899: 221), naiwnych, niezdolnych do tworzenia rzeczy wielkich i trwałych (Sapieha 1899: 203), pełnych dziecięcej ciekawości (Sapieha 1899: 210). Sapieha przyznawał im status „barbarzyńców”, których los odmienił się po pojawieniu się u japońskich wybrzeży amerykańskich statków, by zaraz po tym potwierdzić swoją teorię rozprawą o fanatykach shintoizmu, zdolnych do krwawych zemst na tych, którzy sprzeniewierzali się japońskim tradycjom (Sapieha 1899: 177). Zapałowicz zdaje się z zaskoczeniem

2 Restauracja Meiji - rosnące w Japonii stronnictwa procesarskie oraz reformatorskie doprowadziły w drugiej połowie XIX wieku do obalenia szogunatu i rozpoczęcia okresu głębokich reform społecznych, gospodarczych i politycznych zapoczątkowanych w 1868 roku uroczystą przysięgą cesarską oraz przeniesieniem stolicy państwa z Kioto do Edo (Tokio). Zwieńczeniem czasu drastycznego uprzemysłowienia było wprowadzenie konstytucji (1889 rok), utworzenie parlamentu (189o rok) oraz wkroczenie Japonii na drogę ekspansji w regionie Wschodniej Azji. Zob. np. Tubielewicz 1984: 344-371. 
odnotowywać, że naród japoński jest „nie tylko inteligentny, ale i bardzo domyślny” (Zapałowicz 1899: 207). Lanckoroński rysował portret Japończyków niemających trosk i nieświadomych wagi trudów swojego życia (Lanckoroński 1893: 207, 227). Mimo podziwu dla kunsztu sztuki i tempa rozwoju cywilizacyjnego autorzy wciąż uznawali Japończyków za naród potrzebujący „przewodnika”, który objawiłby im niedolę ich życia i przeprowadził przez kolejne etapy postępu. Co więcej, oznaczało to, że tak jak w przypadku innych społeczności pozaeuropejskich, mieszkańcy Japonii wpisywać mogli się w przekonanie o pierwotnej bliskości z naturą, od której nie oddzieliła ich jeszcze cywilizacja.

Stereotyp bliskości z przyrodą udowadniany jest przez autorów m.in. opisami ogrodów (Sapieha 1899: 220; Lanckoroński 1893: 236, 238; Zapałowicz 1899: 206). Zapałowicz bezpośrednio stawiał ogrodnictwo obok elementów krajobrazu przyrodniczego, gdy rozprawiał o „duchu narodu japońskiego”: „Duch tego narodu [...] przemawiał $\mathrm{z}$ ich zamiłowania w kwiatach, drzewach, wysoko rozwiniętem ogrodnictwie, wodotryskach, wodospadach, sztucznych jeziorach z pysznemi rybami [...]” (Zapałowicz 1899: 190). Japończycy w jego narracji budowali pośród natury i starali się trzymać naturę blisko siebie: „Oto pełno było wszędzie zarośli i sosen, lecz rzadko widziało się lasy. Nie spostrzegało się zato wyrębisk, sprawiających zawsze smutne wrażenie; widoczna, że każdemu Japończykowi miła jest ta jego gromadka drzew i krzaków" (Zapałowicz 1899: 208). Jest to o tyle ważne w kontekście zacierania granic pomiędzy krajobrazem kulturowym i krajobrazem przyrodniczym, że ogrodnictwo, jako sztuka aranżowania przestrzeni dla potrzeb estetycznych i rekreacyjnych, wpisuje się, zgodnie z przedstawionymi wcześniej teoriami, w ramy definicji krajobrazu kulturowego. Mimo to, przez autorów przedstawione jest ono jako dowód na naturalną zdolność Japończyków do współistnienia z przyrodą.

Należy także zwrócić uwagę na rolę poszczególnych elementów naturalnych w opisach architektury japońskiej. Przyroda i dzieło człowieka szczególnie identyfikowane $\mathrm{z}$ miejscową kulturą $\mathrm{w}$ narracjach tych silnie się uzupełniają. Japońska architektura stanowi w ten sposób twór niepełnowartościowy, który znaczenie estetyczne zyskuje dopiero wówczas, jeżeli otoczony zostanie naturą. W ten sposób przedstawiał to Lanckoroński, który przy okazji odwiedzin w kompleksie świątynnym w Nikko zanotował o nim:

Jak z pewnością nikt by sobie nie życzył, aby która ze wspomnianych grup architektonicznych znajdowała się gdzieindziej niż tam, gdzie się znajduje, bo każda $\mathrm{z}$ nich tkwi organicznie w krajobrazie i nawzajem krajobraz uzupełnia [...]. Japońska bowiem architektura tem właśnie różni się od gotyckiej, która właściwie nie znosi bezpośredniego 
otoczenia przyrody, że przeciwnie bez otaczającej zieleni wywierałaby zawsze tylko połowiczne wrażenie (Lanckoroński 1893: 258-259).

Przyroda nie była tutaj jedynie estetycznym uzupełnieniem dzieł architektury, ale otrzymała rolę wypełnienia znaczenia tego, co dopiero w kontakcie z nią nabiera pełnej wartości. Rozdzielenie stylu europejskiego od architektury japońskiej jest w tym przypadku również rozdzieleniem symbolicznym. Gotyk przynależy do miasta - symbolu cywilizacji, podczas gdy budowle japońskie przynależą do natury, stanowią element „pierwotnego”, nieucywilizowanego terytorium. Nie jest to jedyny taki zabieg wprowadzony przez tego autora. Teorię tę udowadniał chwilę wcześniej, notując wrażenia z podróży do miasta: „droga bardzo zła, zato prawie bez przerwy widzisz po obu jej stronach odwieczne cedry i cryptomeria Japonica. Tą najpiękniejszą aleją jaką znam jedzie się ku górom” (Lanckoroński 1893: 256). Przyroda uzupełnia tutaj obraz, dodając znaczenia temu, co w innym otoczeniu nie miałoby żadnej wartości.

Przypadek świątyń w Nikko nie jest odosobniony. Autorzy często łączyli elementy naturalne z miejscami będącymi dziełami rąk ludzkich, które utożsamiali z japońską tradycją i kulturą. Szczególnie wyraziste są przykłady świątyń i herbaciarni. Tak jak góra Fudżi stanowiła naturalny symbol Japonii, tak i świątynie shintoistyczne i buddyskie oraz herbaciarnie wpisywały się w reprezentacyjny obraz tego orientalnego kraju. Składające się na nie przedstawienia bogów i demonów, elementy zdobnicze oraz odprawiane w nich rytuały uosabiały „starożytną” kulturę. Ich „japońskość” dopełniona została opisami otaczającej je przyrody, na którą niejednokrotnie składają się charakterystyczne dla miejscowej flory gatunki drzew i krzewów: „Zatrzymaliśmy się daleko, na brzegu miasta, przed jedną z tych japońskich herbaciarni, rozpowszechnionych w całym kraju. Otaczały ją wyniosłe, starożytne drzewa” (Zapałowicz 1899: 195); „Prawdziwą jednak ozdobą miejscowości [Nara], to ogród czy raczej las otaczający świątynię szintoistów. Pyszne drzewa, wiekiem nieraz pochylone, chryptomena, drzewa kamforowe i zwykłe japońskie sosny” (Sapieha 1899: 205); „Droga wiodła dalej do góry ciągle po pod herbaciarnie z pięknym widokiem do koła, po pod krzywe pinie i krzewy przepysznych azalei, tego szczerojapońskiego kwiatu tak jak pinia jest szczero-japońskiem drzewem. Potem znowu kramy, znowu świątynie [...]” (Lanckoroński 1893: 217); „[...] dostajemy się do jednej z najpiękniejszych świątyń shinto w Japonii [...]. Siedmiopiętrowa pagoda stoi obok jako dzwonnica, otoczona wysokopiennemi kryptomeryami, rodzajem cedru, który rosnąć ma tylko w Japonii” (Lanckoroński 1893: 225).

Wzrok obserwatora skupiony jest na orientalnym charakterze przestrzeni i jej wartości estetycznej, szczegóły jednak umykają w opisach każdemu 
z autorów, nawet jeżeli starają się oni nakreślić przed czytelnikiem charakterystyczne cechy wnętrz budynków i mieszczących się na nich zdobień. Lanckoroński przyznaje na przykład, że sprawia mu trudność odróżnienie świątyń buddyjskich od shintoistycznych, gdyż „tak są podobne do siebie, że się często jest w kłopocie, mając orzec, czy się ma przed sobą świątynię jednej czy też drugiej formy religijnej" (Lanckoroński 1893: 216). Mogli się więc mylić w ocenie świątyń religii, w jakich się znajdowali, a także umykać im mogły widoczne w ich bryłach silne chińskie inspiracje architektoniczne (Barucki 1988: 22-23). Brak wiedzy i obojętność na te elementy stawiały z kolei w centrum opisu „japońskość” przytaczanych miejsc i gatunków roślin.

\section{Krajobraz jako źródło porównania}

Wpływ powierzchowności spojrzenia obserwatora oraz kształtujące percepcję konteksty kulturowe widoczne są na jeszcze jednym poziomie narracji - w porównaniach. Uwidacznia się on szczególnie u Lanckorońskiego, stanowiąc cechę charakterystyczną jego podróżniczych relacji (Kluczewska-Wójcik 2016: 43). Oprócz wspominanych już Etny i Wezuwiusza pojawiają się tu także odniesienia do miast i regionów geograficznych Europy. W ten sposób przedmieścia Tokio przypominały mu galicyjskie miasteczka (Lanckoroński 1893: 205), a samo miasto usytuowane było „tak nad morzem, jak Wiedeń nad Dunajem” (Lanckoroński 1893: 206), widok z wieży twierdzy w Nagoi był „podobny do niejednego z galicyjskich, z Karpatami jako tłem”, pobliski akwen sprowokował opinię, że „Jezioro Biwa równa się zupełnie niektórym alpejskim”, a droga do Kioto wiodła „częściowo ostro niską przełęczą, góry często zalesione, można by pomyśleć, że jest się w Styrii” (Lanckoroński 1893: 234-235). W jego opisach natura nie występuje więc jako samodzielny obiekt poznania, znajduje za to swoje odpowiedniki w bliskim autorowi obszarze geograficznym. Narracja Lanckorońskiego dostarcza również szczególnego przykładu porównania, który wychodzi poza charakterystyczny dla niego układ zestawienia obrazów jako punktów odniesienia dla oceny estetycznej wartości krajobrazu. Pośród opisów pojawia się bowiem portret przestrzeni niderlandzkich, jednak w formie odwróconej względem typowej dla europejskiej narracji kolonialnej.

Już na początku podróży Lanckoroński wspominał o „niderlandzkiej zieleni i niderlandzkich drewnianych domach”, zwrócił jednak uwagę, iż na krajobraz japoński składały się „pagórki zamiast równiny niderlandzkiej, tak, że wszystko jakoś drobniej się wydaje, niż w Holandyi” (Lanckoroński 1893: 205). Oprócz samych porównań, które można by interpretować jako próbę uchwycenia nowych przestrzeni i zamknięcia ich w znanych i zrozumiałych dla czytelników 
obrazach, autor doszukuje się właściwych analogii w przenikaniu kulturowym pomiędzy Niderlandami i Japonią:

W miastach i po wsiach uderza podobieństwo do Holandyi, przypuszczam wszakże, że polega ono właściwie nie tyle na wewnętrznem pokrewieństwie, ile raczej na świadomem czy też bezwiednym naśladownictwie ze strony Holendrów, na których Japonia rzeczywiście w doniosłej mierze wpływ wywarła (Lanckoroński 1893: 233).

Choć nie jest przedmiotem moich rozważań analiza tej ciekawej teorii ukierunkowania przepływu kulturowego, to jednak warto zwrócić na nią uwagę, gdyż na tle analiz stosunków kolonialnych stanowi wyjątek. Jest to bowiem zupełne odwrócenie typowego dla Europejczyków myślenia o kierunku wymiany myśli i idei w relacji Europa - peryferie, które zakładało, że to Stary Kontynent jest źródłem rozwoju cywilizacyjnego i emanuje ideami oświeceniowymi na obszary nieeuropejskie, które ograniczone zostały do „biorcy” osiągnięć kultury europejskiej (Pratt 2011: 196). Przytaczany przez Lanckorońskiego przypadek relacji kulturowej między Holandią i Japonią w otwarty sposób zaprzecza tej teorii. W tym wypadku dotyczy to kraju, który przez wiele lat był jedynym źródłem kontaktu pomiędzy Europą i Japonią jako monopolista handlu z szogunatem Tokugawa. O ile sugestie dotyczące wpływu sztuki czy japońskiej wiedzy medycznej na sztukę i wiedzę Holendrów byłyby uzasadnione (Tybus 2016), to zastanawia ciekawa teza dotycząca wpływu Japonii na przestrzeń niderlandzkich wsi i miast. W sferze domysłów pozostaje, czy autorowi chodziło o osobliwe poczucie estetyki obu narodów, czy może związane było to $\mathrm{z}$ wiedzą i stereotypami dotyczącymi mieszkańców Niderlandów, nie wyjaśnił on bowiem, co dokładnie miał na myśli, pisząc o „świadomem czy też bezwiednym naśladownictwie ze strony Holendrów".

\section{Podsumowanie}

Porównania i kategoryzacja, razem z pozostałymi omówionymi w niniejszym artykule zagadnieniami, stanowią w moim przekonaniu najbardziej wyrazistą część opisu japońskiego krajobrazu, jaki pojawia się w trzech omówionych przeze mnie dziełach. Autorzy, wychodząc z pozycji obserwatorów, za pomocą znanych sobie określeń i zabiegów kreślą nacechowany pozytywnie, a zarazem podrzędny obraz przestrzeni japońskiej, nadając swoim opisom silny wydźwięk kolonialny. Zawieszony między definicjami krajobrazu kulturowego i przyrodniczego, poddawany jest ocenie o profilu estetycznym, która podyktowana jest 
nabranymi uprzednio wyobrażeniami oraz doświadczeniami z odbytych już wcześniej przez autorów podróży. To „krajobrazowa imagologia” oraz ujawniające się nieustannie i intencjonalnie w toku narracji kulturowe zaplecze rządzą sposobem percepcji odwiedzanych przez podróżników krajobrazów i następnie przenoszą się na ich opis. Jednocześnie jednak, tak jak czyni to Lanckoroński w przypadku porównania krajobrazu japońskiego z krajobrazem holenderskim, w szczegółach odbiegają od przyjętych kategorii interpretacyjnych kolonialnego opisu obszarów pozaeuropejskich.

\section{| Bibliografia}

Albertowa Zofia, Kossowski Łukasz (1981), Inspiracje sztuka Japonii w malarstwie i grafice polskich modernistów, Muzeum Narodowe w Kielcach, Muzeum Narodowe w Krakowie, Kielce-Kraków.

Angutek Dorota (2013), Kulturowe wymiary krajobrazu: antropologiczne studium recepcji przyrody na prowincji: od teorii do empirii, Bogucki Wydawnictwo Naukowe, Poznań.

Barucki Tadeusz (1988), Architektura Japonii, Arkady, Warszawa.

Bender Barbara (2014), Odrzucając Zachodnie Spojrzenie: kreślenie map światów alternatywnych, w: Krajobrazy. Antologia tekstów, red. Beata Frydryczak, Dorota Angutek, Wydawnictwo Poznańskiego Towarzystwa Przyjaciół Nauk, Poznań, s. 261-276.

Cosgrove Denis E. (2014), Krajobraz i europejski zmyst wzroku - przygladanie się naturze, w: Krajobrazy. Antologia tekstów, red. Beata Frydryczak, Dorota Angutek, Wydawnictwo Poznańskiego Towarzystwa Przyjaciół Nauk, Poznań, s. 79-110.

Dobrowolska Maria (1948), Dynamika krajobrazu kulturowego, „Przegląd geograficzny", t. XXI, nr 3-4, s. 151-203.

Frydryczak Beata (2013), O zakotwiczeniu krajobrazu w kulturze, „Prace Kulturoznawcze", nr 15, s. 161-169.

Goody Jack (2009), Kradzież historii, przeł. Jacek Dobrowolski, Wydawnictwo Naukowe PWN, Warszawa.

Kluczewska-Wójcik Agnieszka (2016), Japonia w kulturze i sztuce polskiej końca XIX i początków XX wieku Wydawnictwo Tako, Warszawa-Toruń.

Kossowski Łukasz, Martini Małgorzata (2016), Wielka fala. Inspiracje sztuka Japonii w polskim malarstwie i grafice, Wydawnictwo Tako, Warszawa-Toruń.

Kowalczykowa Alina (1982), Pejzaż romantyczny, Wydawnictwo Literackie, Kraków. 
Król Anna (2011), Japonizm polski-Polish Japanism, Muzeum Sztuki i Techniki Japońskiej Manggha, Kraków.

Lanckoroński Karol (1893), Na około ziemi 1888-1889: wrażenia i poglądy, Gebethner i spółka, Kraków.

Loomba Ania (2011), Kolonializm/Postkolonializm, przeł. Natalia Bloch, Wydawnictwo Poznańskie, Poznań.

Myga-Piątek Urszula (2016), Krajobraz jako autentyk, makieta, hybryda. Rozważania o roli krajobrazu we współczesnej turystyce, „Turystyka Kulturowa”, nr 1, s. 47-63.

Pratt Mary Louise (2011), Imperialne spojrzenie. Pisarstwo podróżnicze a transkulturacja, przeł. Ewa Elżbieta Nowakowska, Wydawnictwo Uniwersytetu Jagiellońskiego, Kraków.

Rybicka Elżbieta (2014), Geopoetyka. Przestrzeń i miejsce we wspótczesnych teoriach i praktykach literackich, Universitas, Kraków.

Said Edward W. (2005), Orientalizm, przeł. Monika Wyrwas-Wiśniewska, Zysk i S-ka Wydawnictwo, Poznań.

Sapieha Paweł (1899), Podróż na Wschód Azji 1888-1889, Gubrynowicz i Schmidt, Lwów.

Szczęsny Tadeusz (1982), Ochrona przyrody i krajobrazu, wyd. 4 zm. i uzup., Państwowe Wydawnictwo Naukowe, Warszawa.

Tubielewicz Jolanta (1984), Historia Japonii, Zakład Narodowy im. Ossolińskich, Wrocław.

Tybus Maciej (2016), Holendersko-japońskie związki kulturowe i inspiracje Japonia w sztuce holenderskiej XVII stulecia, Wydawnictwo Tako, Warszawa-Toruń.

Winiewicz-Wolska Joanna (2010), Karol Lanckoroński i jego wiedeńskie zbiory, Zamek Królewski na Wawelu, Kraków.

Zapałowicz Hugo (1899), Jedna z podróży naokoło ziemi, Drukarnia „Słowa Polskiego", Lwów.

\section{| Abstrakt}

Oliwia Gromadzka

Krajobraz japoński w polskich narracjach podróżniczych przełomu lat 8o. i 90. XIX wieku

Celem niniejszego artykułu jest analiza portretu krajobrazu japońskiego, jaki wyłania się z polskich tekstów podróżniczych końcówki XIX wieku. Przeanalizowane 
zostały trzy (a zarazem wszystkie, które są znane) teksty polskich podróżników: Karola Lanckorońskiego, Pawła Sapiehy oraz Hugona Zapałowicza. Pod koniec lat osiemdziesiątych XIX wieku niezależnie od siebie odbyli oni podróż do Japonii. Przedmiotem refleksji są tu poszczególne cechy narracji, takie jak porównania, reprezentacje krajobrazowe, relacje międzykulturowe czy stereotypy dotyczące społeczeństw nieeuropejskich, które złożyły się na charakterystyczny, nacechowany kolonialnym spojrzeniem, opis tego kraju.

Słowa kluczowe: krajobraz, kolonializm, podróżopisarstwo, Japonia, Karol Lanckoroński, Paweł Sapieha, Hugo Zapałowicz

\section{| Abstract}

\section{Oliwia GromadzKa}

\section{Japanese Landscape in Polish Travel Writing in 188 os and 1890 s}

The article aims to analyze the portrait of the Japanese landscape that emerges from Polish travel writing published in late $19^{\text {th }}$ century. Three (and thus all known) texts written by Polish travelers Karol Lanckoroński, Paweł Sapieha and Hugo Zapałowicz are analyzed. The authors traveled independently to Japan at the end of 188 os. The reflection focuses on the individual features of the narrative, such as comparisons, landscape representations, intercultural relations or stereotypes about non-European societies, which constitute a distinctive description of Japan characterized by a colonial view.

Keywords: landscape, colonialism, travel writing, Japan, Karol Lanckoroński, Paweł Sapieha, Hugo Zapałowicz

\section{| Biogram}

Oliwia Gromadzka - mgr, Uniwersytet im. Adama Mickiewicza w Poznaniu. Zainteresowana dziejami europejskiego kolonializmu w XIX i XX wieku, historią regionu Azji Wschodniej w XIX i XX wieku oraz zagadnieniami z zakresu dyskursu postkolonialnego.

E-mail: oliwia.gromadzka@amu.edu.pl

ORCID: 0000-0002-2081-527X 